\title{
Resveratrol inhibits the intracellular calcium increase and angiotensin/ endothelin system activation induced by soluble uric acid in mesangial cells
}

\author{
G. Albertoni and N. Schor \\ Divisão de Nefrologia, Departamento de Medicina, Universidade Federal de São Paulo, São Paulo, SP, Brasil
}

\begin{abstract}
Resveratrol (Resv) is natural polyphenol found in grapes. This study evaluated the protective effect of Resv against the effects of uric acid (UA) in immortalized human mesangial cells (ihMCs). inMCs were preincubated with Resv $(12.5 \mu \mathrm{M})$ for $1 \mathrm{~h}$ and treated with UA $(10 \mathrm{mg} / \mathrm{dL})$ for 6 or $12 \mathrm{~h}$. The intracellular calcium concentration $\left[\mathrm{Ca}^{2+}\right]$ i was quantified by fluorescence using flow cytometry. Angiotensinogen (AGT) and pre-pro endothelin-1 (ppET-1) mRNA were assayed by quantitative real-time RTPCR. Angiotensin II (AII) and endothelin-1 (ET-1) were assayed by ELISA. UA significantly increased $\left[\mathrm{Ca}^{2+}\right]$ i. Pre-incubation with Resv significantly reduced the change in $\left[\mathrm{Ca}^{2+}\right]$ i induced by UA. Incubation with UA for 6 or $12 \mathrm{~h}$ also increased AGT mRNA expression and All protein synthesis. Resv blunted these increases in AGT mRNA expression and All protein. Incubation with UA in the inMCs increased ppET-1 expression and ET-1 protein synthesis at 6 and $12 \mathrm{~h}$. When ihMCs were pre-incubated with Resv, UA had a significantly diminished effect on ppET-1 mRNA expression and ET-1 protein synthesis at 6 and $12 \mathrm{~h}$, respectively. Our results suggested that UA triggers reactions including All and ET-1 production in mesangial cells. The renin-angiotensin system may contribute to the pathogenesis of renal function and chronic kidney disease. Resv can minimize the impact of UA on AII, ET-1 and the increase of $\left[\mathrm{Ca}^{2+}\right] \mathrm{i}$ in mesangial cells, suggesting that, at least in part, Resv can prevent the effects of soluble UA in mesangial cells.
\end{abstract}

Key words: Resveratrol; Intracellular calcium; Angiotensin; Endothelin; Mesangial cells; Uric acid

\section{Introduction}

Resveratrol (Resv), a phenolic compound with significant biological activity, is of great interest to several research groups worldwide $(1,2)$. Dietary intake of Resv in grapes, red wine, peanuts, purple grape juice, and berries may have beneficial effects on human heath (1-7), and may have health-promoting antinephrolithic, antidiabetes, anticancer, antioxidation, anti-inflammation, cardioprotective, chemopreventive, and neuroprotective properties (5-9). In addition, Resv may prevent renal lipotoxicity and have antihyperuricemic activity $(10,11)$.

Several pathways are thought to be related to the protective effect of Resv. In a nephrolithic model, about $70 \%$ of kidney stones were composed of calcium oxalate $(\mathrm{CaOx})$, which causes renal cell injury through the production of reactive oxygen species (ROS) and nicotinamide adenine dinucleotide phosphate (NADPH) when deposited in kidney tissue (12). Resv exerts its antinephrolithic potential via the inhibition of ROS, monocyte chemoattractant protein-1 (MCP-1), hyaluronan, and osteopontin (OPN) signaling (13). Resv has been shown to suppress the migration of oxalate-treated human renal epithelial cells (HRCs), It also can attenuate the expression of NADPH oxidase subunit, MCP-1, and OPN mRNAs, and downregulate the expression of transforming growth factor- $\beta$ (TGF- $\beta 1$ ), TGF- $\beta$ receptor and hyaluronan proteins in oxalate-treated HRCs (13).

Diabetic nephropathy is a serious complication of type 1 and type 2 diabetes. It is characterized by an expansion of the glomerular mesangium caused by mesangial cell proliferation and an excess of extracellular matrix (ECM) proteins synthesized by mesangial cells (14). There is increasing evidence that overproduction of ROS is involved in the development of diabetic nephropathy $(15,16)$ by activating protein kinase $C$, mitogen-activated protein (MAP) kinases, and transcription factors nuclear factor kappa beta $(\mathrm{NF}-\kappa \mathrm{B})$ and activated protein-1. The

Correspondence: N. Schor <nestor@nefro.epm.br>

Received April 12, 2014. Accepted September 10, 2014. First published online October 24, 2014. 
resulting altered expression of genes and ECM proteins leads to diabetic nephropathy (17). Mesangial cell proliferation and fibronectin expression are induced by hyperglycemia through the janus kinase (JNK)/NF-kB/ NADPH oxidase/ROS signaling pathway (14). Resv has been shown to inhibit hyperglycemia-induced mesangial cell expansion and fibronectin expression by blocking this signaling pathway (14).

Hyperuricemia, present as a metabolic disorder, is usually associated with gout, kidney disease, hypertension, cardiovascular diseases, inflammation, diabetes and metabolic syndrome. There is increasing evidence that hyperuricemia is an independent risk factor for the occurrence and development of kidney disease, including damage to mesangial cells. At least one study reported that Resv has antihyperuricemic and nephroprotective activity in oxonate-induced mice (18). These effects, mediated by changes in renal expression of mGLUT9, mABCG2, mOAT1, and mOCT1, are evidence of the possible preventive efficacy of Resv on hyperuricemia $(11,18)$. The present study analyzed the effects of Resv on uric acid (UA)-treated mesangial cells as well as effects on the renin-angiotensin system (RAS) and the endothelin system.

\section{Material and Methods}

\section{Cell culture}

Immortalized human mesangial cells (ihMCs), kindly provided by Dr. Richard Banas (Munich, Germany), were grown in Dulbecco's modified eagle medium (DMEM; Gibco, USA) with the addition of $10 \%$ fetal bovine serum (FBS; Gibco), $24 \mathrm{mM} \mathrm{NaHCO} 3$ (Merck, USA), $10 \mathrm{mM}$ HEPES (Sigma, USA) and 10,000 U/L penicillin/streptomycin (Gibco). The cultures were incubated at $37^{\circ} \mathrm{C}$ in a humidified atmosphere containing $5 \%$ carbon dioxide. When semiconfluent, the cells were detached from the plastic flasks with trypsin $(0.5 \%$; Cultilab, Brazil), centrifuged for $5 \mathrm{~min}$ at $1000 \mathrm{~g}$, and then resuspended in DMEM and subcultured in $22-\mathrm{cm}^{2}$ plastic culture flasks for further experimental procedures.

\section{Resv preparation}

Resv of $99 \%$ purity (Sigma) was dissolved in DMSO (Merck), and stored at $-20^{\circ} \mathrm{C}$ in the dark.

\section{Uric acid preparation}

UA (Sigma) was sterilized in a steam autoclave and added to culture medium without FBS. The UA crystals were suspended in DMEM containing $1 \%$ FBS, incubated at $37^{\circ} \mathrm{C}$, and sonicated for $15 \mathrm{~min}$ to solubilize the crystals.

\section{Exposure of the inMCs to uric acid}

Prior to the experiments, inMCs were transferred to a plastic plate $\left(1 \times 10^{6}\right.$ cells/plate $)$ and maintained under culture conditions for 3 days. At confluence, the cells were exposed for 6 or $12 \mathrm{~h}$ to either DMEM, without FBS, for the control or DMEM containing $10 \mathrm{mg} / \mathrm{dL} U \mathrm{UA}$.

\section{RNA isolation, reverse transcription and quantitative real-time PCR}

Total RNA was isolated and purified from inMCs by a phenol and guanidine isothiocyanate-cesium chloride method, using the appropriate kit (Trizol; Life Technologies, USA). Two micrograms of total RNA were treated with DNase (RQ1 RNase-Free DNase; Promega, USA) to prevent genomic DNA contamination. The RNA pellet was resuspended in RNase-free water and was reverse transcribed into cDNA by the addition of $0.5 \mathrm{mg} /$ $\mathrm{mL}$ oligo $\mathrm{d}(\mathrm{T}), 10 \mathrm{mM}$ dithiothreitol (DTT), $0.5 \mathrm{mM}$ dNTPs (GE Healthcare, UK), and $200 \mathrm{U}$ reverse transcriptase enzyme (SuperScript RT, Gibco, USA).

Real-time amplification was carried out with a 7500 RealTime Sequence Detection System (SDS; ABI Prism 7500; Applied Biosystems, USA). The real-time PCR product was quantified using an intercalating dye (SYBR Green I; Molecular Probes Inc., USA) that exhibits increased fluorescence upon binding double-stranded DNA.

The relative gene expression was calculated using the conditions at the early stages of the PCR. At this point, the amplification is logarithmic and can thus be correlated to the initial copy number of the gene transcripts. The reactions were cycled 40 times under the conditions previously determined by conventional PCR. The fluorescence for each cycle was quantitatively analyzed using an ABI Prism 7500 SDS (Applied Biosystems). At the end of the PCR reaction, the temperature was increased from $60^{\circ} \mathrm{C}$ to $95^{\circ} \mathrm{C}$ at a rate of $2^{\circ} \mathrm{C} / \mathrm{min}$. During that time, fluorescence was measured every $15 \mathrm{~s}$ to construct a melting curve. A nontemplate control was run with each assay.

The PCR was performed with primers specific for pre-pro endothelin-1 (ppET-1), angiotensinogen (AGT), and $\beta$-actin. The primer sequences were: $p p E T-1$ sense (5'-GAGAAACCCACTCCCAGTCC-3') and antisense (5'-GATGTCCAGGTGGCAGAAGT-3'); $\beta$-actin, sense (5'-TCACCCACACTGTGCCCATCTACGA-3') and antisense (5'-CAGCGGAACCGCTCATTGCCAATGG-3'); and $A G T$ sense (5'-ACTTCTCGGTGACTCAAGTGCC-3') and antisense (5'-GAAAGTGAGACCCTCCACCTTGT-3'). The results of these experiments are reported in each group as the relative expression normalized to the $\beta$-actin housekeeping gene. This gene was used as an internal control and is expressed here as a percentage of the control reaction.

\section{Real-time data analysis}

The cycle threshold $(\mathrm{Ct})$ values were subtracted from the $\mathrm{Ct}$ value for each gene to yield the $\Delta \mathrm{Ct}$ values. These values were used for statistical comparisons. For the graphic representations, the fold variation was determined using the $2^{-(\Delta \Delta C t)}$ method according to published protocols (19) and manufacturer recommendations. The fold variations were calculated by determining the difference in 
the $\Delta \mathrm{Ct}$ values between the chosen reference and the test samples ( $\Delta \Delta \mathrm{Ct}$ value), with subsequent application of the $2^{-(\Delta \Delta C t)}$ formula.

\section{Enzyme-linked immunosorbent assay (ELISA)}

The concentrations of angiotensin II (AII) and endothelin (ET)-1 were assayed in cell cultures treated with UA using a commercially available competitive ELISA (Cayman Chemical, USA). All assays were performed according to the manufacturer's protocols. The absorbance of each sample was determined using an Ultra Microplate (Biotek, USA) and reported as $\mathrm{ng} / \mathrm{mL}$ and $\mathrm{pg} / \mathrm{mL}$.

\section{Measurement of intracellular calcium by flow cytometry}

For the cytometric analyses, the cells were cultured to a density of $2 \times 10^{6}$ cells/well, were pretreated with Resv $(12.5 \mathrm{uM})$ and stimulated with UA $(10 \mathrm{mg} / \mathrm{dL})$. The cells were then trypsinized, washed twice with PBS, and resuspended in $0.5 \mathrm{~mL}$ isotonic solution. The osmolarity of the isotonic solution was $323 \pm 6 \mathrm{mOsm}$ and consisted of $80 \mathrm{nM}$ D-mannitol with $120 \mathrm{mM} \mathrm{NaCl}, 6 \mathrm{mM} \mathrm{KCl}, 1 \mathrm{mM}$ $\mathrm{MgCl}_{2}, 2 \mathrm{mM} \mathrm{CaCl}_{2}$, and $5.4 \mathrm{mM}$ HEPES. The cells were loaded with $2 \mu \mathrm{M}$ fluo-4/AM (Invitrogen, USA) for $30 \mathrm{~min}$ and were analyzed by flow cytometry (BD FACSCanto II, BD Biosciences, USA) at an excitation wavelength of $488 \mathrm{~nm}$ and an emission wavelength of $525 \mathrm{~nm}$. The fluorescence intensity of approximately $1 \times 10^{6}$ labeled cells was measured in each assay, and the data are reported as the median fluorescence intensity in arbitrary units $(A U)$ obtained by averaging at least 3 separate experiments (20).

\section{Statistical analysis}

The data are reported as means \pm SE. The experimental and control groups were compared via the Student $t$-test. The significance level for the null hypothesis was set at $5 \%(P<0.05)$.

\section{Results}

Resv inhibited the increase in $\left[\mathrm{Ca}^{2+}\right] \mathrm{i}$ induced by UA

To study the effect of Resv on mesangial cells, the effect of UA was first analyzed. Treatment of inMCs with $10 \mathrm{mg} / \mathrm{dL}$ UA increased $\left[\mathrm{Ca}^{2+}\right] \mathrm{i}(80.60 \pm 0.20)$ compared with the fluorescence at baseline, but the increase in All was greater than that of $\left[\mathrm{Ca}^{2+}\right] \mathrm{i}$ after UA administration. The effect of UA was inhibited by pre-exposure of mesangial cells to Resv. When the inMCs were preincubated with $12.5 \mu \mathrm{M}$ Resv for $1 \mathrm{~h},\left[\mathrm{Ca}^{2+}\right] \mathrm{i}$, as estimated by fluorescence intensity, was $38.34 \pm 0.01$ compared to $80.60 \pm 0.20$ in cells that had not been pretreated $(\mathrm{P}<0.005$; Figure 1).

Resv inhibited the RAS system in the mesangial cells One of the main regulators of contraction in mesangial cells is the peptide All; therefore, we evaluated the effect of Resv on UA-induced All synthesis. There was a significant increase in UA-induced AGT mRNA expression in the ihMCs in a time-dependent manner. Incubation of the inMCs with $10 \mathrm{mg} / \mathrm{dL}$ UA significantly increased AGT mRNA expression at $6 \mathrm{~h}(12.40 \pm 0.92$ vs $1.24 \pm 0.18 \mathrm{AU}$ for the control, $\mathrm{P}<0.001)$ and at $12 \mathrm{~h}$ (22.04 \pm 0.79 vs $1.24 \pm 0.18 \mathrm{AU}$ for the control, $\mathrm{P}<0.001)$. When inMCs were pre-incubated with $12.5 \mu \mathrm{M}$ Resv for $1 \mathrm{~h}$, the increase in AGT mRNA was not as great at $6 \mathrm{~h}$ $(12.40 \pm 0.92$ vs $3.03 \pm 1.08 \mathrm{AU}$ for the UA condition) and at $12 \mathrm{~h}(22.04 \pm 0.79$ vs $5.36 \pm 1.06 \mathrm{AU}$ for the UA condition) (both $P<0.001$, Figure $2 A$ ).

$\mathrm{UA}$ increased All protein synthesis at $6 \mathrm{~h}(0.07 \pm 0.01$ vs $0.05 \pm 0.01 \mathrm{ng} / \mathrm{mL}$ for the control, $\mathrm{P}<0.05)$ and $12 \mathrm{~h}$ $(0.10 \pm 0.01$ vs $0.05 \pm 0.01 \mathrm{ng} / \mathrm{mL}$ for the control, $\mathrm{P}<0.05)$ Pre-incubation with $12.5 \mu \mathrm{M}$ Resv for $1 \mathrm{~h}$ attenuated the increase in All protein synthesis at $6 \mathrm{~h}(0.05 \pm 0.01 \mathrm{vs}$ $0.07 \pm 0.01 \mathrm{ng} / \mathrm{mL}$ for the UA group) and at $12 \mathrm{~h}$ $(0.04 \pm 0.003$ vs $0.10 \pm 0.01 \mathrm{ng} / \mathrm{mL}$ for the UA group) (both $\mathrm{P}<0.05$, Figure 2B).

\section{Resv inhibited the endothelin system in mesangial cells}

ET-1 is also a peptide involved in smooth muscle cell contraction (21). Nevertheless, the effect of UA on ET-1 synthesis in mesangial cells is not known. UA significantly increased ppET-1 mRNA expression in cultured inMCs in a time-dependent manner. Incubation of the inMCs with UA increased ppET-1 expression at $6 \mathrm{~h}(1.52 \pm 0.23 \mathrm{vs}$ $1.02 \pm 0.10 \mathrm{AU}$ for the control group) and $12 \mathrm{~h}$ (2.32 \pm 0.18 vs $1.02 \pm 0.10 \mathrm{AU}$ for the control group) (both $P<0.05$, Figure 3A). When the inMCs were pre-incubated with $12.5 \mu \mathrm{M}$ Resv for $1 \mathrm{~h}$, the increases were significantly

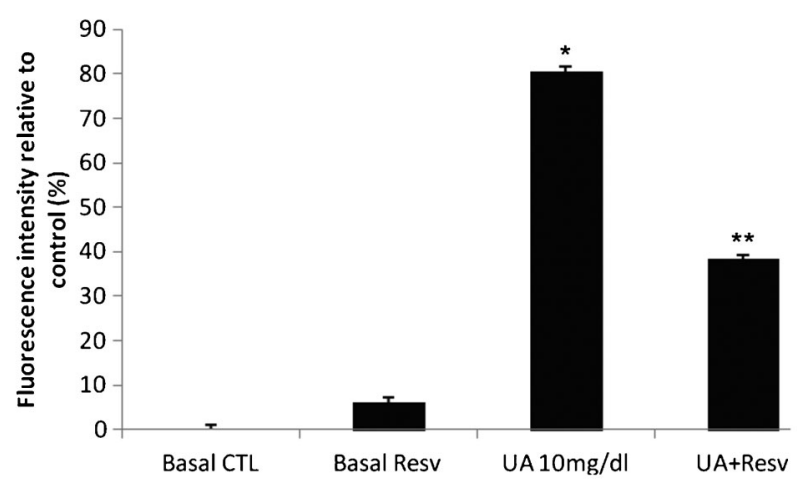

Figure 1. Intracellular calcium concentration in immortalized human mesangial cells (ihMCs) treated with uric acid (UA) and resveratrol (Resv). Briefly, semi-confluent ihMC cells were detached with trypsin and the fluorescence intensity of intracellular calcium was determined by Fluo-4/AM in the presence of $10 \mathrm{mg} / \mathrm{dL}$ UA and $12.5 \mu \mathrm{M}$ Resv. Data are reported as the mean percentage ( $\pm \mathrm{SE})$. ${ }^{*} \mathrm{P}<0.001$ vs control $(\mathrm{CTL})$; ${ }^{* *} \mathrm{P}<0.005$ vs UA (Student $t$-test). 

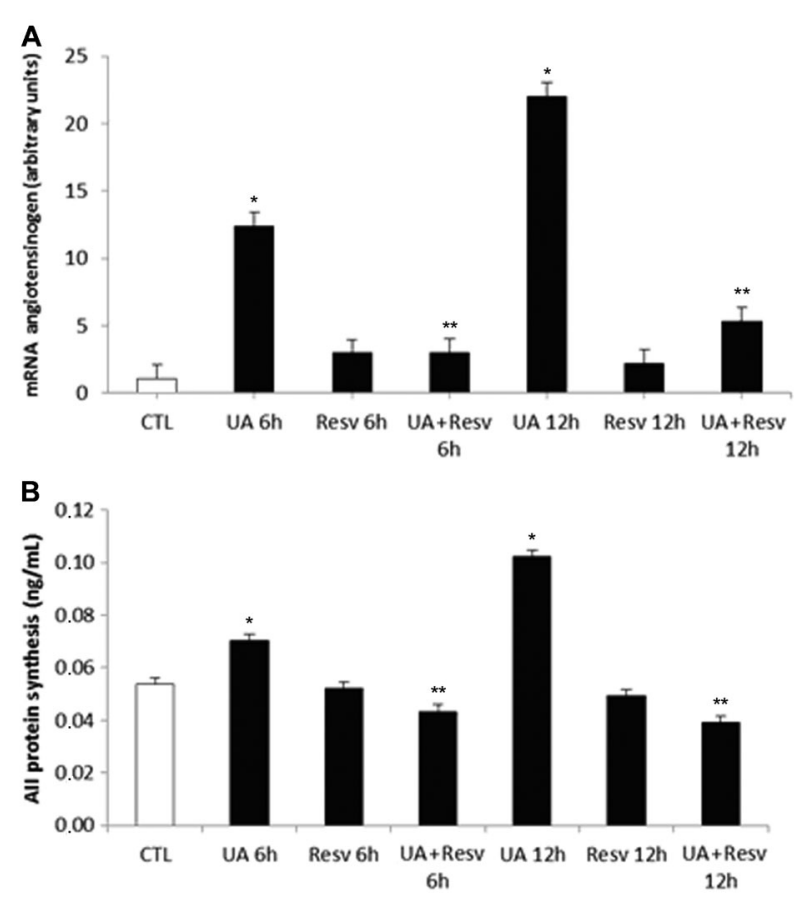

Figure 2. Effect of resveratrol (Resv) treatment on the angiotensinogen mRNA expression $(A)$ and All protein synthesis $(B)$ in immortalized human mesangial cells (ihMCs) stimulated with uric acid (UA). Cells were seeded onto plates and after 6 and $12 \mathrm{~h}$ were exposed to DMEM with $1 \%$ FBS containing $10 \mathrm{mg} / \mathrm{dL}$ $\mathrm{UA}$, and $12.5 \mu \mathrm{M}$ Resv. Data are reported as means $\pm \mathrm{SE}$. ${ }^{*} \mathrm{P}<0.001$ vs control $(\mathrm{CTL}) ;{ }^{*} \mathrm{P}<0.001$ vs UA (Student $t$-test).

lower at both $6 \mathrm{~h}(0.77 \pm 0.18$ vs $1.52 \pm 0.23$ arbitrary units for the UA group) and $12 \mathrm{~h}(0.41 \pm 0.06$ vs $2.32 \pm 0.18$ arbitrary units for the UA group (both $\mathrm{P}<0.05$, Figure $3 \mathrm{~A}$ ).

UA increased ET-1 protein synthesis at $6 \mathrm{~h}$ (32.69 \pm 0.22 vs $29.68 \pm 0.35 \mathrm{pg} / \mathrm{mL}$ for the control group) and $12 \mathrm{~h}(37.29 \pm 1.23$ vs $29.68 \pm 0.35 \mathrm{pg} / \mathrm{mL}$ for the control group (both $\mathrm{P}<0.05$, Figure $3 \mathrm{~B}$ ).

Again, when the inMCs were pre-incubated with $12.5 \mu \mathrm{M}$ Resv for $1 \mathrm{~h}$, the increases were significantly lower in ET-1 protein synthesis at $6 \mathrm{~h}(27.78 \pm 1.38 \mathrm{vs}$ $32.69 \pm 0.22 \mathrm{pg} / \mathrm{mL}$ for the UA group) and at $12 \mathrm{~h}$ $(29.92 \pm 1.02$ vs $37.29 \pm 1.23 \mathrm{pg} / \mathrm{mL}$ for the UA group (all $\mathrm{P}<0.05$, Figure $3 \mathrm{~B}$ ).

\section{Discussion}

Mesangial cells play a major role in glomerular contraction and regulate filtration surface area and ultrafiltration coefficient $(\mathrm{Kf})$ through the release of hormones such as All. Mesangial cells express all components of RAS, and can regulate the $\mathrm{Kf}$ via contraction or the release of vasoactive hormones (22). ETs are also powerful vasoconstrictor peptides, and act as modulators of vasomotor tone, cell proliferation, and hormone production. Mesangial cells are the main site of
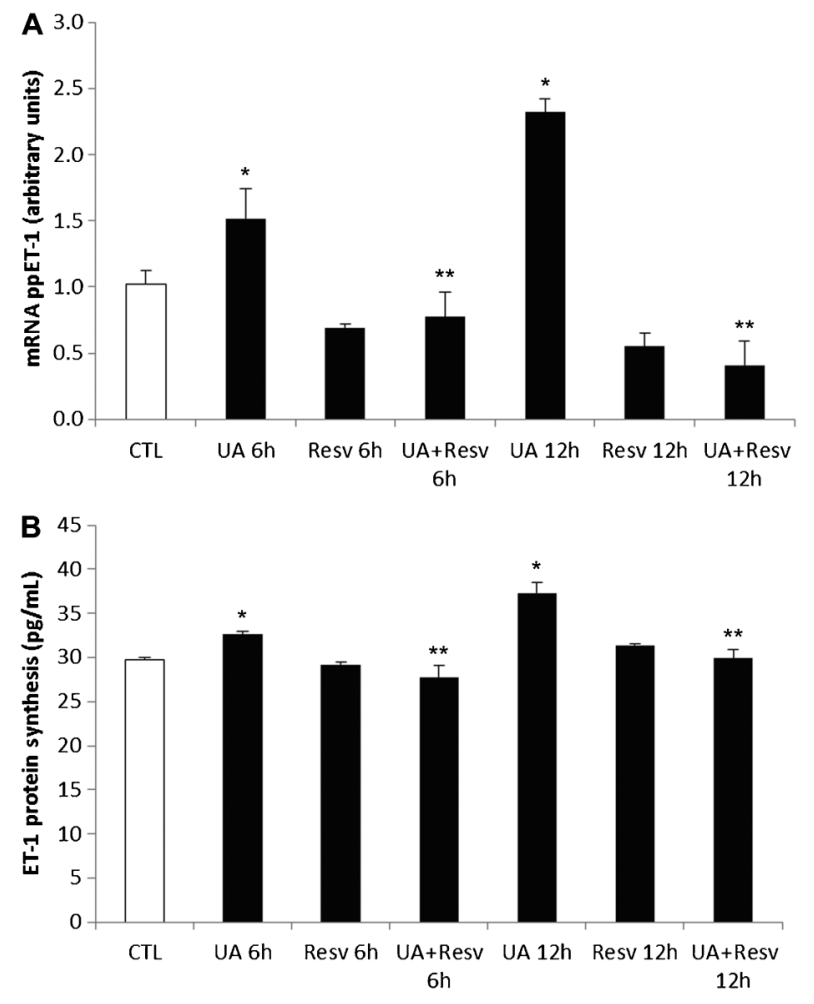

Figure 3. Effect of resveratrol (Resv) treatment $(12.5 \mu \mathrm{M})$ on mRNA pre-pro endothelin-1 (ppET-1) expression $(A)$ and ET-1 protein synthesis $(B)$ in immortalized human mesangial cells (ihMCs) stimulated with uric acid (UA). Cells were seeded on plates and after 6 and $12 \mathrm{~h}$ were exposed to DMEM with $1 \%$ FBS containing $10 \mathrm{mg} / \mathrm{dL} \cup A$ and $12.5 \mu \mathrm{M}$ Resv. Data are reported as means \pm SE. $A,{ }^{*} \mathrm{P}<0.05$ vs control $(\mathrm{CTL}) ;{ }^{* *} \mathrm{P}<0.05$ vs UA (Student $t$-test). $B,{ }^{*} \mathrm{P}<0.05$ vs $\mathrm{CTL} ;{ }^{*} \mathrm{P}<0.001$ vs UA (Student $t$-test).

ET production in the kidney (23).

UA has recently been recognized as a key factor in multifactorial renal disorders, including chronic kidney disease, hypertension and acute kidney injury $(24,25)$. Recent studies have confirmed that RAS is strongly related to elevated serum UA levels in hypertensive patients. We have previously demonstrated that UA stimulates RAS and ET-1 in mesangial cells after $24 \mathrm{~h}$ (26). Experimental studies in vitro have also demonstrated that UA has direct effects on rat vascular smooth cell, proliferation (27), human vascular endothelial cell dysfunction (28), and ihMC proliferation (26) via local tissue RAS activation. This evidence indicates that the activation of systemic and local tissue RAS by UA may be partially responsible for the pathogenetic effects of UA in hypertension.

The experimental choice of $10 \mathrm{mg} / \mathrm{d}$ UA was determined by the saturation concentration of monosodium urate in human plasma of approximately $7 \mathrm{mg} / \mathrm{dL}$. Thus, the definition of hyperuricemia is usually a plasma UA concentration $>7 \mathrm{mg} / \mathrm{dL}$ (29). In addition, Aida et al. (30) 
reported that the plasma concentration of UA in the general population has a wide range, extending from 1 to $12 \mathrm{mg} / \mathrm{dL}$. Observations in an American cohort were confirmed in a community-based study with participants in Vienna that reported mild hyperuricemia in patients with uric acid concentrations of $7.0-8.9 \mathrm{mg} / \mathrm{dL}$ (31). High UA concentrations ( 5 or $15 \mathrm{mg} / \mathrm{dL}$ ) upregulated both RAS mRNA expression and All II protein secretion in 3T3-L1 adipocytes. In addition, UA caused a significant increase in ROS production in differentiated adipocytes (32).

Evidence from studies indicates that the generation of ROS is, at least in part, involved in endothelial dysfunction $(33,34)$, and the production of ROS, particularly the superoxide anion $\left(\mathrm{O}_{2}^{-}\right)$, is closely related to calcium concentration (35).

The concentration of Resv $(12.5 \mu \mathrm{M})$ was chosen from among various concentrations that are known to have relevant cardiovascular effects on isolated tissues or organs (36). The first evidence of the specific benefits of red wine was shown in 1993 when Frankel et al. (37) demonstrated that red wine diluted 1000 -fold and containing $10 \mu \mathrm{mol}$ of total phenols inhibited the oxidation of LDL. This is approximately the Resv concentration found in red wines, and suggested that half a bottle of such wine should contain an active concentration of resveratrol (37).

In a study similar to ours, Chao et al. (38) found that Resv $(10 \mu \mathrm{M})$ inhibited the formation of All-induced ROS, extracellular signal-regulated kinase phosphorylation, ET-1 gene

\section{References}

1. Scott E, Steward WP, Gescher AJ, Brown K. Resveratrol in human cancer chemoprevention - choosing the 'right' dose. Mol Nutr Food Res 2012; 56: 7-13, doi: 10.1002/ mnfr.201100400.

2. Roupe KA, Remsberg CM, Yanez JA, Davies NM. Pharmacometrics of stilbenes: seguing towards the clinic. Curr Clin Pharmacol 2006; 1: 81-101, doi: 10.2174/ 157488406775268246.

3. Smoliga JM, Baur JA, Hausenblas HA. Resveratrol and health - a comprehensive review of human clinical trials. Mol Nutr Food Res 2011; 55: 1129-1141, doi: 10.1002/mnfr.201100143.

4. Delmas $D$, Aires $V$, Limagne $E$, Dutartre $P$, Mazue $F$, Ghiringhelli $F$, et al. Transport, stability, and biological activity of resveratrol. Ann N Y Acad Sci 2011; 1215: 48-59, doi: 10.1111/j.1749-6632.2010.05871.x.

5. Timmers S, Konings E, Bilet L, Houtkooper RH, van de Weijer T, Goossens GH, et al. Calorie restriction-like effects of 30 days of resveratrol supplementation on energy metabolism and metabolic profile in obese humans. Cell Metab 2011; 14: 612-622, doi: 10.1016/j.cmet.2011.10.002.

6. Brasnyo P, Molnar GA, Mohas M, Marko L, Laczy B, Cseh $\mathrm{J}$, et al. Resveratrol improves insulin sensitivity, reduces oxidative stress and activates the Akt pathway in type 2 diabetic patients. $B r J$ Nutr 2011; 106: 383-389, doi: 10.1017/S0007114511000316.

7. Magyar K, Halmosi R, Palfi A, Feher G, Czopf L, Fulop A, et al. Cardioprotection by resveratrol: A human clinical trial expression, and cell proliferation in smooth muscle cells.

In this study, UA induced an increase in ppET-1 mRNA expression and protein synthesis after 6 and $12 \mathrm{~h}$ and increased AGT mRNA expression and All protein synthesis after 6 and $12 \mathrm{~h}$. In addition, Resv reduced UAinduced pre-proET-1 gene expression and the production of All and ET-1 in mesangial cells, suggesting that it can minimize the impact of these hormones on glomerular function. In addition, Resv inhibited the increase in $\left[\mathrm{Ca}^{2+}\right]$ i. These results are the first direct evidence that UA induces an increase in $\left[\mathrm{Ca}^{2+}\right]$ i that is minimized by Resv. Our results suggested that UA triggers reactions including All and ET-1 production in mesangial cells. RAS may contribute to the pathogenesis of renal function and chronic kidney disease. Resv can minimize the impact of UA on the increases of All, ET-1 and $\left[\mathrm{Ca}^{2+}\right] \mathrm{i}$ in mesangial cells, suggesting that it can prevent the effects of soluble UA on mesangial cells.

Lastly, multidisciplinary approaches are recommended for future investigations because of the wide range of polyphenol actions on body fat reduction, mitigation of liver disease, improvements in muscle function, and cardiovascular and renal protection.

\section{Acknowledgments}

Research supported by CNPq, FINEP, FAPESP, CAPES, and Fundação Oswaldo Ramos (FOR).

in patients with stable coronary artery disease. Clin Hemorheol Microcirc 2012; 50: 179-187.

8. Kondratyuk TP, Park EJ, Marler LE, Ahn S, Yuan Y, Choi Y, et al. Resveratrol derivatives as promising chemopreventive agents with improved potency and selectivity. Mol Nutr Food Res 2011; 55: 1249-1265, doi: 10.1002/mnfr.201100122.

9. Matsuoka A, Kodama Y, Fukuhara K, Honda S, Hayashi M, Sai K, et al. A pilot study of evaluation of the antioxidative activity of resveratrol and its analogue in a 6-month feeding test in young adult mice. Food Chem Toxicol 2008; 46: 1125-1130, doi: 10.1016/j.fct.2007.11.008.

10. Kim MY, Lim JH, Youn HH, Hong YA, Yang KS, Park HS, et al. Resveratrol prevents renal lipotoxicity and inhibits mesangial cell glucotoxicity in a manner dependent on the AMPK-SIRT1-PGC1alpha axis in db/db mice. Diabetologia 2013; 56: 204-217, doi: 10.1007/s00125-012-2747-2.

11. Shi YW, Wang CP, Liu L, Liu YL, Wang X, Hong Y, et al. Antihyperuricemic and nephroprotective effects of resveratrol and its analogues in hyperuricemic mice. Mol Nutr Food Res 2012; 56: 1433-1444, doi: 10.1002/mnfr.201100828.

12. Khan SR. Hyperoxaluria-induced oxidative stress and antioxidants for renal protection. Urol Res 2005; 33: 349357, doi: 10.1007/s00240-005-0492-4.

13. Hong SH, Lee HJ, Sohn EJ, Ko HS, Shim BS, Ahn KS, et al. Anti-nephrolithic potential of resveratrol via inhibition of ROS, MCP-1, hyaluronan and osteopontin in vitro and in vivo. Pharmacol Rep 2013; 65: 970-979, doi: 10.1016/ 
S1734-1140(13)71078-8.

14. Zhang L, Pang S, Deng B, Qian L, Chen J, Zou J, et al. High glucose induces renal mesangial cell proliferation and fibronectin expression through JNK/NF-kappaB/NADPH oxidase/ROS pathway, which is inhibited by resveratrol. Int J Biochem Cell Biol 2012; 44: 629-638, doi: 10.1016/ j.biocel.2012.01.001.

15. Ha H, Hwang IA, Park JH, Lee HB. Role of reactive oxygen species in the pathogenesis of diabetic nephropathy. Diabetes Res Clin Pract 2008; 82 (Suppl 1): S42-S45, doi: 10.1016/j.diabres.2008.09.017.

16. Forbes JM, Coughlan MT, Cooper ME. Oxidative stress as a major culprit in kidney disease in diabetes. Diabetes 2008; 57: 1446-1454, doi: 10.2337/db08-0057.

17. Kashihara N, Haruna Y, Kondeti VK, Kanwar YS. Oxidative stress in diabetic nephropathy. Curr Med Chem 2010; 17: 4256-4269, doi: 10.2174/092986710793348581.

18. Shi YW, Wang CP, Liu L, Liu YL, Wang X, Hong Y, et al. Antihyperuricemic and nephroprotective effects of resveratrol and its analogues in hyperuricemic mice. Mol Nutr Food Res 2012; 56: 1433-1444, doi: 10.1002/mnfr.201100828.

19. Livak KJ, Schmittgen TD. Analysis of relative gene expression data using real-time quantitative PCR and the 2(-Delta Delta C(T)) method. Methods 2001; 25: 402-408, doi: $10.1006 /$ meth.2001.1262.

20. Adebiyi A. RGS2 regulates urotensin Il-induced intracellular $\mathrm{Ca}^{2+}$ elevation and contraction in glomerular mesangial cells. J Cell Physiol 2014; 229: 502-511, doi: 10.1002/jcp.24470.

21. Chuang TY, Au LC, Wang LC, Ho LT, Yang DM, Juan CC. Potential effect of resistin on the ET-1-increased reactions of blood pressure in rats and $\mathrm{Ca}^{2+}$ signaling in vascular smooth muscle cells. J Cell Physiol 2012 ; 227: 1610-8, doi: 10.1002/jcp.22878.

22. Sorokin A. Endothelin signaling and actions in the renal mesangium. Contrib Nephrol 2011; 172: 50-62, doi: $10.1159 / 000328680$.

23. Woodward OM, Kottgen A, Coresh J, Boerwinkle E, Guggino WB, Kottgen M. Identification of a urate transporter, ABCG2, with a common functional polymorphism causing gout. Proc Natl Acad Sci U S A 2009; 106: 10338-10342, doi: 10.1073/pnas.0901249106.

24. McElnea EM, Quill B, Docherty NG, Irnaten M, Siah WF, Clark AF, et al. Oxidative stress, mitochondrial dysfunction and calcium overload in human lamina cribrosa cells from glaucoma donors. Mol Vis 2011; 17: 1182-1191.

25. Pasalic D, Marinkovic N, Feher-Turkovic L. Uric acid as one of the important factors in multifactorial disorders - facts and controversies. Biochem Med 2012; 22: 63-75, doi: 10.11613/BM.2012.007.

26. Albertoni G, Maquigussa E, Pessoa E, Barreto JA, Borges $F$, Schor N. Soluble uric acid increases intracellular calcium through an angiotensin II-dependent mechanism in immortalized human mesangial cells. Exp Biol Med 2010; 235:
825-832, doi: 10.1258/ebm.2010.010007.

27. Corry DB, Eslami P, Yamamoto K, Nyby MD, Makino H, Tuck ML. Uric acid stimulates vascular smooth muscle cell proliferation and oxidative stress via the vascular reninangiotensin system. J Hypertens 2008; 26: 269-275, doi: 10.1097/HJH.0b013e3282f240bf.

28. Yu MA, Sanchez-Lozada LG, Johnson RJ, Kang DH. Oxidative stress with an activation of the renin-angiotensin system in human vascular endothelial cells as a novel mechanism of uric acid-induced endothelial dysfunction. J Hypertens 2010; 28: 1234-1242.

29. Baldree LA, Stapleton FB. Uric acid metabolism in children. Pediatr Clin North Am 1990; 37: 391-418.

30. Aida Y, Shibata Y, Osaka D, Abe S, Inoue S, Fukuzaki K et al. The relationship between serum uric acid and spirometric values in participants in a health check: the Takahata study. Int J Med Sci 2011; 8: 470-478, doi: 10.7150/ijms.8.470.

31. Obermayr RP, Temml C, Knechtelsdorfer M, Gutjahr G Kletzmayr J, Heiss S, et al. Predictors of new-onset decline in kidney function in a general middle-european population. Nephrol Dial Transplant 2008; 23: 1265-1273, doi: 10.1093/ $\mathrm{ndt} / \mathrm{gfm} 790$.

32. Zhang JX, Zhang YP, Wu QN, Chen B. Uric acid induces oxidative stress via an activation of the renin-angiotensin system in 3T3-L1 adipocytes. Endocrine 2014

33. Doughan AK, Harrison DG, Dikalov SI. Molecular mechanisms of angiotensin II-mediated mitochondrial dysfunction: linking mitochondrial oxidative damage and vascular endothelial dysfunction. Circ Res 2008; 102: 488-496, doi: 10.1161/CIRCRESAHA.107.162800.

34. Wassmann S, Stumpf M, Strehlow K, Schmid A, Schieffer B, Bohm M, et al. Interleukin-6 induces oxidative stress and endothelial dysfunction by overexpression of the angiotensin II type 1 receptor. Circ Res 2004; 94: 534-541, doi: 10.1161/01.RES.0000115557.25127.8D.

35. Victor VM, Apostolova N, Herance R, Hernandez-Mijares A, Rocha M. Oxidative stress and mitochondrial dysfunction in atherosclerosis: mitochondria-targeted antioxidants as potential therapy. Curr Med Chem 2009; 16: 4654-4667, doi: 10.2174/092986709789878265

36. Opie LH, Lecour S. The red wine hypothesis: from concepts to protective signalling molecules. Eur Heart $J$ 2007; 28: 1683-1693, doi: 10.1093/eurheartj/ehm149.

37. Frankel EN, Kanner J, German JB, Parks E, Kinsella JE. Inhibition of oxidation of human low-density lipoprotein by phenolic substances in red wine. Lancet 1993; 341: 454457, doi: 10.1016/0140-6736(93)90206-V.

38. Chao HH, Juan SH, Liu JC, Yang HY, Yang E, Cheng TH, et al. Resveratrol inhibits angiotensin II-induced endothelin1 gene expression and subsequent proliferation in rat aortic smooth muscle cells. Eur J Pharmacol 2005; 515: 1-9, doi: 10.1016/j.ejphar.2005.03.035. 